Roland Ahlstrand

Malmö University

Faculty of Education and Society

Department of the Individual and Society

Phone +46 (0)40 6658005, 070-33 38003

\title{
Integrative Strategy, Competitiveness and Employment: A Case Study of the Transition at the Swedish Truck Manufacturing Company Scania During the Economic Downturn in 2008-2010
}

\begin{abstract}
The purpose of the article is to investigate how and why the truck manufacturer Scania adapted to the economic downturn between 2008 and 2010 in the manner it did: First, Scania signed a crisis agreement on fewer working hours and lower wages, and, later, it signed an agreement stipulating fewer working hours, but without wage reductions. Both of these agreements were combined with investments in competence development and education as well as with the decision not to give notice to the employees, which was uncommon among Swedish companies. It is claimed that the company wanted to strengthen the competitiveness by integrating the unions and the employees even more in the business. An important prerequisite was the company's Flexibility Agreement, which allowed the company not to give temporary employees new contracts and to let temporary employees leave the company as soon as their maximum employment period of six months expired.
\end{abstract}

Keywords: Integrative strategy, restructuring, collective bargaining, continuous improvement work, competitiveness and employment. 


\section{Introduction}

During the rapidly deteriorating business cycle in the autumn of 2008 and the winter of 2009, lay-offs were made within the Swedish industry of a magnitude not seen since the depression years of the 1930s (Kjellberg, 2011). As a result, the Swedish Association of Engineering Employers and other employer associations signed a historical one-year "Crisis Agreement" on 2 March 2009 with the blue-collar union IF Metall. The agreement led to local negotiations on proposals to reduce working hours by up to 20 percent as well as a corresponding reduction of the monthly wage, which resulted in local crisis agreements in about 400 companies (Teknikföretagen, 2009). One such agreement was reached in May 2009 between the Swedish truck manufacturer Scania and IF Metall as well as the white-collar unions Unionen, the Association of Managerial and Professional Staff and the Swedish Association of Graduate Engineers. The agreement stipulated a four-day workweek at 90 percent of the original wages; further, it ensured that no one would be given notice during the period of the agreement. In December 2009, just before the crisis agreement expired, Scania concluded a new agreement with the trade unions. This agreement was said not to be a local crisis agreement because it was concluded within the framework of the existing collective agreement and did not stipulate any wage reduction during the four-day workweek. As with the local crisis agreement, it also included an agreement not to give notice to any of the employees during the agreement period. In addition, both of these agreements ran parallel with investments in competence development and education for all blue-collar workers. In this way, Scania's handling of the economic downturn differed from other Swedish companies, whose crisis agreements did not include deals not to give notice to employees and were mostly not combined with investments in skills development and education (Gruvornas Arbetsgivareförbund et al., 2011). For instance, in the Volvo group some of the companies did invest in competence development; however, they, as well as other Swedish companies, gave notice to many of their employees. To answer the questions of why Scania pursued this course of action and how it was accomplished, 
I will argue in this article that the aim of the company was to strengthen the competitiveness by integrating the unions and the employees even more in the business. Furthermore, I will also argue that it was important for the management to get legitimacy from the unions and the employees for maintaining the workers' involvement in continuous improvement work. Another factor to be considered is the relations between the company and the unions being embedded in years of cooperation regarding production systems, employment and competitiveness not only on the Scania level but also on the central and national levels.

This article starts by identifying the characteristics of the Swedish model for restructuring companies. Concepts such as collective, integrative and distributive bargaining will be put in a context of labour law and transition agreements. Next, the research questions and methodology are considered through a case study, based on qualitative methods, of Scania's adjustment to the downturn. Also considered is the method, including the interviews and seminars with representatives of Scania and the trade unions. Subsequently, the study is situated by describing the context of the labour market parties' quest for developing the production systems in terms of employment and competitiveness. It is further situated by detailing the context of Scania's handling of economic fluctuations by collective agreements as well as its management's interest in employee participation and achieving legitimacy for continuous improvement work. Next, the empirical data from the Scania study is presented in terms of five themes: the use of flexibility agreements; competence development, education and legitimacy; integrative bargaining in the spring of 2009; integrative bargaining in the autumn of 2009; and termination of competence development and education. Finally, the conclusions of the study are presented. Among the questions to be answered are: How did the employers convince the unions to agree to business cycle-adjusted working hours and corresponding wage reductions, which the unions had previously strongly resisted? What was the strategic action from the unions in the wake of the crisis agreements? Was Scania's way of handling the downturn the most advanced when compared to other Swedish companies' ways of managing the crisis? 


\section{Characteristics of the Swedish model of restructuring}

Previous research on corporate restructuring in Sweden has often referred to the RehnMeidner model from the late 1950s: In this model, high-productivity companies would set the standard for the wage levels (the solidaristic wage policy), which would lead to the displacement of low-productivity companies. Employees in low-productivity companies would be transferred to high productivity companies with so-called active labour market policies (e.g., the Public Employment Service, labour market training and internships). However, in the present article, the point of departure is taken in the phenomenon of collective bargaining, which is central not only in the Swedish model of restructuring (Bergström and Diedrich, 2008) but also in the Swedish model of the relations between the labour market parties since the Saltsjöbaden Agreement of 1938 (Lundh, 2010:303). Initially, three laws concerning collective bargaining in times of restructuring should be mentioned. First, the Co-determination Act (Medbestämmandelagen, MBL), which regulates the information that employers are obliged to give trade unions; it says that employers that are bound by collective agreements have to inform and consult trade unions on any important change in the company that can impact employees. The second law is the Employment Protection Act (Lagen om anställningsskydd, LAS), which regulates the employees' security of employment. For instance, it prohibits undue notice of dismissal and summary dismissal and contains rules on selection criteria, which are semi-compulsory. The third, and final, relevant law is the Employment Promotion Act (Främjandelagen, FL), which stipulates that the employer is obliged to notify the Public Employment Service of cutbacks in operations that will affect at least five employees.

On the basis of these laws, collective bargaining has resulted in a number of new agreements that regulate dismissals as well as the market for support in restructuring processes since the crisis of the early 1990s (Bergström and Diedrich, 2008; Bäckström, 2006; Edström and Sabel, 2005). Several of the agreements consist of so-called transition agreements, which now cover almost the entire Swedish labour market. The Transition Agreement between, for instance, the Confederation of Swedish Enterprise 
and the Swedish Trade Union Confederation (2004) means that companies and local trade unions can apply for grants from Trygghetsfonden TSL (an insurance system founded by the parties) to get external support in the case of redundancies. Trygghetsfonden TSL has signed a number of agreements with staffing companies that offer transition programs. These programs include individual and group activities in order to (1) identify the individual's ability to get a new job, develop individual action plans and obtain internships and (2) provide guidance and assistance in seeking new employment.

However, there have also been a lot of transition agreements at company level (Ahlstrand, 2006). Mostly, the programs offer dismissed employees prolonged dismissal periods and transfer packages, including job-search training, counseling and other activities to support the transfer of employees to other jobs (Bergström and Diedrich, 2008). This kind of program was, for instance, current when the telecom company Ericsson restructured in the beginning of the twenty-first century and reduced personnel by more than 23,000 employees in Sweden (Ahlstrand, 2006, 2010). The program came into being after four months of negotiations not only between the management and the trade unions but also the Public Employment Service, the County Labour Board, the County Administrative Board, the Municipality of Norrköping (the first site for the restructuring) and the Employment Security Council. The employees were offered a twelve-month support programme in a staffing company, a supplementary salary for up to twelve months if they got a job at a lower wage, and a salary for twelve months if they began to study. The employees were also assisted on a daily basis with analyses of their qualifications, information retrieval, job-search assistance, development of individual plans of action, study counselling and finding trainee positions.

Collective bargaining in itself has an emphasis on integrative bargaining (cf. Musial, 1999), which is often discussed in contrast to distributive bargaining (Kochan, 1992; Walton and McKersie, 1991). Integrative bargaining aims at finding complementary or even common interests and solving the problems confronting both employers and unions, resulting in a variable-sum game (Garaudel et al., 2008; cf. Walton and McKersie, 1991:5). An example of the situation would be where the employer agrees to 
limit the number of redundancies or to reduce general working hours while the employees agree to reopen discussions on pay structure or work pace (Sisson and Artiles, 2000). Integrative bargaining, often initiated by the company, means that the management is usually willing to include items that previously were regarded as falling within its prerogative, such as future investment or the implementation of changes in work organisation (Sisson, 2001; Marginson, 2010). According to Freyssinet and Seifert (2001), integrative bargaining covers also the safeguarding of employment or an increase in jobs, the maintenance of production sites and the inclusion of measures designed to boost competitiveness.

Distributive bargaining, however, aims at resolving pure conflicts of interest and is known for the view that bargaining concerns winning or losing in a fixed-sum or zerosum game (Garaudel mfl, 2008; Sisson, 2001; Walton and McKersie, 1991:4). It is said to be a more traditional way of bargaining, and it has often been restricted to wages, working time and safety. The strategic choice by the management will typically be to secure a maximum gain for the company in the short term, meaning there is less trust to preserve (Ilsöe, 2012). Finally, it should be said that distributive bargaining is frequently seen as contrary to integrative bargaining; this could be misleading. In practice, bargaining often includes both distributive and integrative bargaining.

To sum up, the Swedish model of restructuring-with collective bargaining at its center, backed up by law-is characterised by integrative bargaining, collective agreements, partnerships and regulation by the parties involved.

\section{Method}

The study of Scania's transitions was carried out during the spring and autumn of 2010 and the spring of 2011. Interviews were conducted with representatives of the trade unions and company's management at both the corporation and local levels (Södertälje and Oskarshamn, respectively) as well as with production leaders and production personnel (Oskarshamn). The interviews were conducted in separate rooms and offices and, a couple of times, combined with guided tours with managers and production 
leaders in the production. Interviewees were selected on the basis of discussions with executive staff and at the suggestion of persons who had already been interviewed. According to one of the selection criteria, the interviewees were to have broad or more specific knowledge of the company's transitions, which comprised, among other things, of negotiations, agreements, cost cuts and work organisation. The interviews (19 in total) lasted from one-and-a-half to two hours.

The study was also based on a collection of project documentation as well as on information obtained from websites and newspaper articles. The project documentation consisted of agreements, project descriptions, educational materials, organisational descriptions, evaluations and outcome follow-ups. Information obtained from websites included company introductions, trade union positions and press releases. The newspaper articles, frequently personal accounts, were obtained from the union press and daily newspapers and contained reports, op-ed features and interviews. In addition, the study included a number of meetings with members of Scania Oskarshamn's two management groups and of the reference group formed in connection with the present research project. On these occasions, executives as well as human resource personnel and trade union representatives gave their views on the company's transitions during the economic downturn.

The empirical material was processed in several stages. One stage involved transcribing the digitised interview recordings and further elaborating on the notes taken during interviews and meetings with the management and reference groups. Another stage was to clarify the relative timing of what were judged to be more significant decisions and events. The purpose was to reduce the risk that certain decisions and events would appear disproportionately important. During a third stage, themes appearing in the interview material were identified using a combination of four techniques (Ryan and Bernard, 2003): theory-related material, repetitions, similarities and differences, and missing data. In this case, using the technique referred to as "theory-related material" meant starting out from theory-driven research questions and, from there, focusing on decisions, chains of events and interactions between management, the trade unions and the employees. "Repetitions" was a matter of 
discerning topics that frequently occurred in the material, whereas "similarities and differences" concerned finding both concordant and conflicting views on Scania's transition process. Finally, "missing data" referred to complementing the empirical material through further contacts and interviews with Scania's employees.

The themes thus discerned were as follows:

- The use of the flexibility agreements

- Competence development, education and legitimacy

- Integrative bargaining in the spring of 2009

- Integrative bargaining in the autumn of 2009

- Termination of competence development and education

Preliminary versions of the themes and their contents were discussed in the meetings of the reference group and the research group, which consisted of three colleagues also doing research in Scania. However, before proceeding to the themes, the study will be situated within the historical context of the Swedish employers' and trade unions' quest for developing companies' production systems. In this way, I intend to show that the parties have developed an increasingly close cooperation in order to face increased competition from competitors; this has, for instance, been expressed in the industrial agreements from 1997 and 2011 as well as through the integration of the union interest in a "good work" and the management interest in Japanese production systems with its focus on the workers' commitment to continuous improvement work. I believe this was important for what happened in Scania during the economic downturn between 2008 and 2010.

\section{The labour market parties' quest for developing production systems}

The labour market parties' has for a long time worked for developing the production systems in Swedish companies. During the 1970s and 1980s, it was reflected in, for instance, the Swedish Employers' Confederation's (SAF's) report "Different kinds of Factories" (1979), the development agreement between SAF, The Swedish Trade Union 
Confederation (LO) and The Federation of Salaried Employees in Industry and Services (PTK) (1982), and the congress report of the Swedish Metalworkers' Union, "The Good Work" (1985). The SAF report "Different kinds of Factories" suggested four criteria for a good production system and, to a certain extent, good work (Abrahamsson and Johansson, 2008): small, autonomous production systems; decoupling between employees and machine; engaging work roles; and reliable and effective production systems. The development agreement meant that SAF, LO and PTK undertook work for increased effectiveness, profitability and competitiveness (Kjellberg 1992:125). It resulted in several research programs, financed by the Swedish Working Life Fund (Brulin \& Nilsson 1991:337). One of these was the development program, which aimed to investigate the possibilities for developing work content and work organisation as well as productivity and competitiveness together with the introduction of new technology. Another research program was the LOM-program (Leadership, Organisation, Codetermination), which sought to gain knowledge about new ways of developing competence and commitment in employees. Characteristic for both of these programmes was the efforts to support local initiatives to change (cf. Rehn \& Viklund, 1990:320). Finally, the metalworkers union report "The Good Work" favoured adaptation to changes in the corporate environments (Metall, 1985) and said the industry had to adjust to existing circumstances. The report not only underlined a shift from production orientation (economies of scale) towards market orientation (flexibility and customisation) (see Abrahamsson and Johansson, 2008:5), it also recommended a group-based work organisation with continuous training and a gradually vertical and horizontal integration of work tasks in combination with new wage forms (e.g., bonus systems and convertibles). ${ }^{1}$

In the beginning of the 1990s, and parallel with a productivity crisis in the Swedish industry (SOU 1991:82), the interest for developing the production systems was influenced by the way Japanese companies, particularly in the auto industry, organised their production. Swedish employers and union leaders listened, as many others in the

\footnotetext{
1 The ideas in "The Good Work" were further developed in the following congress reports Solidary labour policy for the good work (1989), and Solidarity for work, development and justice (1993).
} 
international arena did, to what was said to be best practice, not least the scholars who argued that the whole world should adopt "lean production" (Womack et al 1990). ${ }^{2}$ Japanese organisational principles were by no means undisputed. Some Swedish unions were particularly sceptical and strongly opposed an uncritical acceptance and application of these principles (Metall 1992a, 1992b and 1993, and SIF 1992a and 1992b). Employment conditions in the Japanese auto industry were not considered to be at the same level as for employees in the Swedish industry. Researchers, in Sweden and abroad, argued that Japanese companies and companies influenced by Japanese companies organised labour in the direction of increased oppression and subordination, or, put another way, standardised work improperly (Berggren, 1992; Berggren, Björkman \& Hollander, 1991; Parker \& Slaughter, 1988; Fucini and Fucini, 1990; Garrahan and Stewart, 1992).

However, the industry as a whole argued that Lean production and just-in-time principles, such as workers commitment to continuous improvement work, led to better quality and higher productivity in the Japanese auto industry as compared with the rest of the world (cf. Björkman 1991:107-128, Metall 1992c and Edling and Sandberg 1996:317-336). It was also clear that the Japanese production systems could be applied in the transition from mass production to customised production, which the companies assessed to be necessary. In support of such a transition, new wage systems were introduced to increase the skill development necessary for the workers in production to fulfil their tasks and to reach a high level of flexibility in the work organisation:

The principle, simply, is that the more tasks and the more difficult tasks the individual member of the team takes on, the better paid he or she should be. The

\footnotetext{
2 In general, it was considered important to understand that Japanese production systems mobilised workers' intelligence as well as physical skill (Kenney \& Florida, 1993); they contributed to a situation in which the world's rich nations were unlikely to need any manpower (Rifkin, 1995), and they were based on "high-trust relations" (Fukuyama, 1995). Japanese production systems became an imperative not only in the auto industry, which once again had a paradigmatic importance (Jürgens, Malsch \& Dohse, 1993:2), but also far beyond this industry - it became a key component even in resolving social and economic problems of nations and regions (Brulin \& Nilsson, 1995:9-12). Conventional discussions of the economy - GDP, economic growth, the country's competitiveness and forecasts of the future of the economy - were occasionally meaningless (Reich, 1994:14).
} 
purpose of this wage system is to signal to the team members that they should make an effort to learn and develop at work. (Nilsson, 1999)

Further, the wage systems often included group-based performance supplements (i.e., bonus systems) based on quality, lead times, the use of material and so forth, as well as individual competence factors such as social competence, initiative and problem-solving ability. To take on new production systems, the employers even wanted to see the ban on private employment agencies and temporary employment abolished. The wish was fulfilled: The ban was removed in 1993 (cf. Bergström, Håkansson, Isidorsson and Walter, 2007:39), giving speed to the expansion of the staffing business and the industry's use of staffing personnel, whose share could quickly be adapted to the demand.

In the light of the productivity crisis - and the decentralisation of traditionally centralised bargaining on agreements and wages to the industry level (Thörnqvist, 1999; Kjellberg, 2009; Thörnquist and Engstrand, 2011:15) - the labour-market parties initiated negotiations on the development of the production systems. In the Agreement on Industrial Development and Wage Formation (of March 1997), commonly known as the Industrial Agreement, the new direction was consolidated. The agreement not only covered virtually the whole competitive sector of the Swedish economy; it bridged old class distinctions on the trade union side between blue- and white-collar workers, and it presented an entirely new model for collective bargaining and conflict resolution (Elvander, 2002). Under the heading "Common Assessments and Views", it described the common understanding of industrial production systems and how it should be developed regarding international competition, changing economic conditions, competitive strength and education, training, and competence development. The agreement was further developed in the next industrial agreement, concluded in the summer of 2011. The new industrial agreement strengthened the normative role of the industry through new rules for how negotiations would proceed, but it also identified three areas where cooperation between the parties was considered to be of particular 
importance: education, research and innovation, and strong industrial settings and corporate productivity (Teknikföretagen, 2011).

All together, discussions on production system issues became more informal and inclusive on the company level. One reason for this was that the companies' objective of increasing efficiency was met by the development of "integrated" production systems, which meant a combination of the union interest in good work and the management interest in Japanese production systems (e.g., partly a movement away from tayloristic and bureaucratic steering principles) (Brulin and Nilsson, 1995). Consequently, it became common that trade unions took part in decision-making in the companies and that discussions on production questions were no longer settled as part of the traditional negotiation system but through a kind of informal joint consultation process (Nilsson, 1999). Today, both managers and union representatives are deeply involved in adapting the dominant idea on effective production systems (Lean production) to the Swedish context (Brulin et al, 2012). In this respect, the truck manufacturer Scania, whose restructurings during the recession will be analysed, seems to have greatly benefitted from the collaboration with the vehicle manufacturer Toyota-the most known representative for Japanese production systems - since the mid-1990s (cf. Sederblad, 2013).

\section{Scania's way of handling economic fluctuations}

\section{Collective agreements}

Being one of the world's largest manufacturers of trucks over 16 metric tons and with 35,000 employees (in 2008), Scania constituted 13 percent of the European truck manufacturing market and 26 percent of the Brazilian market. The production of components occurs partly in Sweden (with the head office in Södertälje), and partly in Brazil and Argentina. Assembly takes place in Sweden, Holland, France and Brazil (Scania, 2008). The enterprise is considered to be highly sensitive to economic fluctuations. Like other truck manufacturers, the company has experienced sharply decreased sales volumes in connection with economic downturns (Fagerström, 2004:1). 
In Sweden, the company have used the collective bargaining system to regulate the labour costs according to the demand. One of the agreements that have been concluded, the Agreement concerning Flexibility and Security of Employment (the so-called Flexibility Agreement ${ }^{3}$ from 2002), regulates temporary employment and the hiring of blue-collar workers. According to this agreement, 30 percent of the workforce may consist of temporarily employed personnel (mainly assembly personnel) for periods of a maximum of six months. In other words, if the company has hired 30 percent of its personnel on a temporary basis, this personnel category may be promptly cut back. Furthermore, the agreement limits hiring from staffing companies to cases of illness, absence or parental leave for more than two weeks and less than eight weeks. It also regulates an extended term of notice for permanently employed personnel beyond what is specified by the Employment Protection Act (LAS). The extension means an addition with two, four or six months depending on the length of employment and could, with 10 years of employment, result in a maximum of $12(6+6)$ months term of notice. The extension is said to strengthen job protection and underline the importance of the "core workforce".

Another agreement that have been concluded, the Scania Flexible Working Hours Agreement (the SFA Agreement in brief from 1999), regulates economically adjusted working hours (i.e., working hours in times of prosperity and economic downturn for all the Scania employees). ${ }^{4}$ According to this agreement, a given blue-collar worker's working hours may vary from minus 175 to plus 175 hours relative to ordinary working hours during one calendar year.

However, from 1 September 2011, both of these agreements, the Flexibility Agreement and the Scania Flexible Working Hours Agreement, were replaced by a new agreement between Scania and IF Metall. The most noticeable difference was that temporary personnel (30 percent of the blue-collar workers) now could consist of

\footnotetext{
3 The actual name of the agreement is the "basic agreement concerning flexibility and security of employment", [Huvudavtal avseende flexibilitet och anställningstrygghet]. It was signed in 2002.

${ }^{4}$ Its full name is Framework Agreement Scania Flexible Working Hours [Ramavtal Scania flexibel arbetstid]. It was signed in 1999.
} 
mainly personnel from staffing companies. The purpose was to increase the speed in the numeric flexibility.

In addition, cyclical fluctuations in the economy are countered by the company's module-based product program. This program resembles a construction set, in which most vehicle and engine components can be part of many different combinations. In other words, the modular system allows for assembling a great variety of vehicles using a limited number of components (Scania, 2008). In this way, the modular system can yield considerably longer component production series than conventional product systems can. It helps the company maintain, despite decreased sales volumes, reasonable profitability even during economic downturns (Anjou, 2008: 98). Moreover, the modular system is advantageous given that the company is engaged in production all around the globe. Business cycles are frequently out of phase in different parts of the world. Thus, factories on one continent undergoing an economic downturn may produce components, such as gearboxes and engine parts, for factories where the trade conditions are more favourable.

\section{Employee participation and management legitimacy}

Scania's way of handling economic fluctuations is connected to the blue-collar worker's participation in the development of the production system through continuous improvement work (Ahlstrand and Sederblad, 2012), which, in turn, is intended to increase the company's competitiveness. The connection of interest here is legitimacy (i.e., the legitimacy that management can achieve in relation to the workers). I will attempt to clarify the significance of legitimacy in this regard by saying that since the mid-1990s Scania opted to focus on workshop personnel's participation in developing the production process using Scania's Production System (SPS). The interest in the personnel's participation was a reaction to frequent quality and recruiting problems, a high level of employee turnover, considerable absence due to illness and large inventories. However, it was certainly also an effect of the company's embrace of Japanese ways of organising production systems and the exchange of know-how with a 
Japanese vehicle manufacturer, Toyota (cf. Sederblad, 2013). Taken together, this encouraged the company towards a new way of thinking about the relation between the market and the production system, not least the work organisation and the importance of trust and continuous improvement work. However, the focus on employee participation has aimed at increasing the possibility to develop a visual production flow without buffers or stoppages and supported by a kanban system, in which material and components such as engines, gearboxes, driver's cabs, axles and cabling are delivered to the production unit just-in-time. One element of this work has been to organise the workers into so-called (continuous) improvement groups that, apart from the assembly work, are also engaged in streamlining the production flow: the groups document each stage in the operation to detect and subsequently avoid unnecessary working moments, movements, transports and inventories (cf Anjou, 2008: 125-127).

The improvement work is based on documented questions concerning the groups' work with flow equalisation as well as pacing, balancing and standardisation of the work process. The questions also concern the allocation of areas of responsibility, organisation, order at the workplace, work in improvement groups and visualisation of the work using bulletin boards.

The questions constitute a foundation not only for work in the groups but also for the production leaders' work in analysing and improving SPS. In this context, the work of the production leaders is pedagogical as well. They are expected to explain the purpose of the work done in the improvement groups to the workers. For example, they must be able to explain how the goals of the company are to be achieved, how due regard is to be paid to safety and the environment, and how to avoid overproduction by not beginning the work until the customer (the next part of the production flow) has placed an order (by maintaining buffer capacity).

In this system, where increased efficiency in terms of quality, lead times and other productivity measures depends on the employees' motivation to take an active part in the rationalisation process, management has to convince employees that their involvement will not lead to fewer jobs. In other words, management has to show they will protect their employees' jobs-even in downturns. Accordingly, Scania has 
reinforced the position of permanently-employed personnel by extending their term of notice by two, four or six months, depending on the length of employment. The extended term of notice is regulated in the above-mentioned flexibility agreement between the company and IF Metall, resulting in a maximum notice period of 12 months - a redoubling of the previous maximum period. Thus, in yet another way, the agreement strengthens the permanent employees' employment security: the temporary employees primarily suffer from a recession, not the permanent employees.

\section{Scania's transitions in 2008-2010}

\section{The use of the flexibility agreements}

When the recession hit Scania in the end of 2008, the company used both the Flexibility Agreement and the Scania Flexible Working Hours Agreement. The so-called sentiment indicator, which measures behaviours and psychological factors among actors on the truck market for the year to come, indicated that the market was on its way toward vanishing altogether. In the interviews, the central question occupying the management was said to be regarding future competitiveness. What would happen when trade outlooks eventually improved? How could the company recover from the economic downturn stronger than its competitors? How would the company be able to manage the annual demands for rationalisation and for producing more per individual? One of the managers interviewed put it this way:

What we knew was that an upturn would come: How well are we prepared for it? To think about that. There was an amazing focus on it. The question was what investments can we make in the meantime to lie low now and do better later?

The strategy was to invest in competence development and education to maintain both the continuous improvement work and competitiveness. An important part of this strategy was also to strengthen the legitimacy of the continuous improvement work. Managers meant it was important for continuous improvement work not to be 
understood in terms of fewer work tasks despite an economic downturn and to act according to the company's core value, respect for the individual employee:

Scania is not a company consisting of only machines and equipment. Scania is a company consisting of human beings. As simple as that!

However, as a result of this strategy, cost cuttings were considered to be necessary, despite the financial strength of the company (the company showed the strongest earnings in its history with a net income of SEK 8,890 million (Scania, 2008)). Cost cuttings were implemented using the Flexibility Agreement and the Scania Flexible Working Hours Agreement.

As soon as the company had informed the trade unions according to the Codetermination Act (MBL), the Flexibility Agreement was used for terminating the employment for everyone employed for a limited period when the maximum employment period of six months expired, without giving anyone the common extension. Consequently, costs for about 1,000 temporary employees were reduced quickly, sometimes within the span of only a few weeks, in other cases after some months. It also paved the way for cost cuts regarding lighting and heating because several shifts were eliminated. Giving notice to permanently employed personnel was not considered, both because of upturn preparation, continuous improvement work and respect for the individual in only this particular recession and because the company and the unions had agreed that this group would have stronger job protection in all downturns. Giving notice to permanent employees would have meant relatively long delays due to the extension of the notice periods according to the agreement. The use of the Flexibility Agreement was said to also have meant that the company did not have to get involved in resource-consuming negotiations with the trade unions (according to the Employment Protection Act (LAS)) or the Public Employment Service (according to the Employment Promotion Act (FL)), which otherwise would have been the case.

The other agreement, the Scania Flexible Working Hours Agreement, was, however, not to be applied as it was previously (i.e., by having employees work over their normal working hours and receive compensation for this plustime in the form of time off). As 
one of the union representatives put it, the agreement was to be used the other way around:

We had never done that before. Everything had been all right, and the production had been high, so there was mostly plustime here.

More specifically, the Scania Flexible Working Hours Agreement was applied so that the employees had twelve days off around Christmas and New Year. This time off was then to be made up for in work time as the demand for trucks increased.

\section{Competence development, education and legitimacy}

The use of the collective agreements on flexibility and the strategy for strengthening competitiveness by maintaining the continuous improvement work meant that all workers in Södertälje, Oskarshamn and Luleå (about 6,000) participated in competence development and education. For example, in Oskarshamn, 1,300 workers participated in the programmes on a half-time basis (from January until the vacation period of 2009). During any given week, half of the workforce was engaged in competence development while the other half was working. The following week, they alternated: those who had participated in competence development the week before were now working, and vice versa.

The competence development — which, for example, began in Oskarshamn right after Christmas, when the company had reduced operations from three shifts to onewas strongly linked to the workplace. It was to deal with increased participation in the production process through improvement activities concerning Scania Production System (SPS), health, working environment, products, group coordination, and, for instance, problem solving. Moreover, workers were given opportunities to participate in in-service training at other workplaces both within and outside the company. The education programs - which, in Oskarshamn, also began just after Christmas, and were indirectly supposed to contribute to the continuous improvement work-were carried out in collaboration with the municipal adult education system and concentrated mainly on the primary and secondary core subjects: mathematics, Swedish and English. 
Here, it is difficult not to note that the investments in competence development and education corresponded quite well with common understandings in the industrial agreement between the employers and trade unions on the industry level. The agreement emphasised the importance of investments in competence development and education for developing companies' competitiveness. However, it is hard to determine the immediate importance of the industrial agreement in this case; nevertheless, there was a common understanding even here: the management's decisions were consistent with collective agreements on flexibility as well as several decades of union aspirations concerning competence development and education. For example, during the interviews, a blue-collar representative legitimised the management's strategy and said that "it was really good for employees to get education in Swedish, English, maths and such things." In addition, he was satisfied because the company had "a will to keep personnel" and "there were not only short-sighted capitalists in the world but also those who took a long-term view of what they had to do to lie low during the crisis in order to produce trucks in the future". The unions, as well as the management, expected that the strategy would strengthen the position of the company on the market and increase production rates with a minimum of quality and delivery problems when the economic situation eventually improved.

\section{Integrative bargaining in the spring of 2009}

The company's way of dealing with the economic downturn had so far been relatively uncomplicated; for instance, representatives for the unions said that the management had acted in a responsible and exemplary manner, assuming social responsibility (Scania Inside Oskarshamn, 2009). However, in the spring of 2009, the situation became more complex as Scania's management, according to the interviews, felt it "was forced to come up with new measures" because the recession was "much deeper than anyone had expected." In order to continue with investments in maintaining continuousimprovement work through competence development and education, further savings were considered necessary. To achieve these savings, negotiations with the trade unions 
were initiated, resulting in a package of agreements. One of the negotiations concerned the Scania Flexible Working Hours Agreement regulating the shop personnel's flextime. The bargaining resulted in an agreement to increase the plus-minus hours from 175 to 250 hours a year during the coming year. Another negotiation-not in itself directly linked with cost cutting but very important to IF Metall, the blue-collar unionconcerned the right to re-employment for temporary staff. Union representatives was not satisfied with the precariousness of temporary workers (i.e. the price they had paid for stronger job security for the core workers). The bargaining resulted in an agreement, the substance of which was to extend the right to re-employment for temporary personnel from 9 to 18 months, thus exceeding the 9 months stipulated by the Employment Protection Act (LAS). However, the union ties with temporary workers would later come to weaken with the above mentioned new flexibility agreement in 1 September 2011. The agreement meant that temporary personnel now would consist of mainly personnel from staffing companies.

An additional negotiation, which was described as much more difficult than the first two, concerned management's ambition to bring about an (crisis) agreement on a fourday workweek (normal amount of hours per day) at 90 percent of original wages with both IF Metall and the organisations of salaried employees:

\section{Negotiations with IF Metall}

The negotiations were closely intertwined with the just-finished bargaining at industry level. The Engineering Employers, the Iron and Steel Employers, the Industrial and Chemical Group and Teko (the common business and employers' organisation of Sweden's textile and fashion companies) had, on 2 March, come to a general one-year agreement (i.e. the Crisis Agreement) with IF Metall on a reduction in working hours and wages. It also included an explicit wish that the local parties should make arrangements regarding competence development. Local IF Metall representatives were not entirely pleased with this. One of their counterarguments was that there was a risk that this type of crisis agreement would become permanent and that it constituted a changeover to wages that were conditioned by the state of the market. Another 
counterargument was that a ten percent wage reduction at the 20,000 to 25,000 SEK monthly income level would hit union members fairly hard, particularly, as one of the union representatives said, "if two from the same family work here". Nevertheless, the local unions accepted the management's proposal for a short-time work system, but only after having been faced with the employer's message that the alternative would become dismissals and after having received legitimacy for their decision from their members. The latter was based on referendums organised by the local unions, which was quite uncommon in Swedish working life and illustrated the complexity and novelty of the situation. The result showed that a majority of the 6,000 members supported the crisis agreement (89 percent participated in the referendum). The voting figures, however, differed between the three sites: in Oskarshamn, 53 percent; in Södertälje, 60 percent; and in Luleå, 70 percent was for the local crisis agreement. First, union representatives thought these differences were due to age differences (i.e., that older employees more often were against the crisis agreement than younger ones because they would not be hit in the first place if it came to dismissals). However, after a while, these explanations did not to seem to be enough, according to union representatives. The picture was more complex, they said.

\section{Negotiations with Unionen}

In the case of Unionen, the largest white-collar union at Scania (and in Sweden), the situation was different. Firstly, representatives of the national level opposed a general agreement on a four-day workweek with 90 percent pay. The resistance was, among other things, based on the notion that members would receive smaller unemployment and illness benefits as well as run the risk of being given notice despite the agreement. Secondly, the employers' organisations brought a lawsuit against Unionen at the Labour Court, claiming that the resistance lacked legal support because the collective agreement enabled parties to enter into local crisis agreements. In this situation, representatives of Unionen maintained that the union ran the risk of losing the case, thus offering the local unions the opportunity to enter into local crisis agreements, whereupon the employers withdrew their plaint. Thirdly, the local unions at Scania were positive, which not was 
the case with the local IF Metall representatives. A referendum, which was held some days before the IF Metall referendum, showed that 95 percent of the 2,000 members accepted a local crisis agreement.

\section{The Scania Crisis Agreement}

Scania concluded a local crisis agreement with all of the company's trade unions (i.e., the blue-collar union IF Metall and the white-collar unions Unionen and the Association of Managerial and Professional Staff and the Swedish Association of Graduate Engineers) in the middle of May. During this time, other companies also concluded crisis agreements: Volvo Cars in Gothenburg and Volvo Trucks in Gothenburg and Umeå (Volvo Cars is owned by the Chinese company Geely Automobile, while Volvo Trucks is owned by the Swedish Volvo Group). Volvo Cars concluded its crisis agreement in March, whereas Volvo Trucks concluded its crisis agreement in June. In contrast to Scania, both of these companies gave notice to more than 8,000 permanent employees during 2008 and 2009. However, the Scania agreement was built on concessions both from the unions and from the management. The unions had accepted lower wages and fewer working hours, which the management considered to be an important goal:

The four-day week resulted in a very quick cost reduction. Had we chosen to give notices, there would have been a very long way to go to an actual cost reduction.

The agreement on a four-day workweek meant that the company saved both 10 percent of the salary costs and energy costs on the fifth, non-work, day. The most important concession made by the company to the unions was said to be the guarantee that employees would get unchanged benefit rates in case of illness or unemployment and that notice could not be given during the period of the agreement. The agreement remained in force from 1 June through 31 December 2009. 5

\footnotetext{
5 The agreement actually had two parts, one of which was in force from June 1 through June 26, the other from August 1 through December 31, 2009. The reason for this division was uncertainty as to whether employees would be allowed keep their previous benefit levels from the unemployment benefit fund and the social insurance office if the agreement also included the month of July.
} 


\section{Integrative bargaining in the fall of 2009}

Both the competence development and the education programmes continued during autumn 2009. There was, indeed, a reduction in time spent on competence development and education, from every other week to three-and-a-half hours every morning, four days a week. Similarly, there was an increase in job activity. The personnel certainly had more to do: the inventory of ready-built trucks was running out; the demand for components had developed positively at the company's plant in Brazil and the temporary personnel were no longer employed. Moreover, the company's application for support from the European Social Fund (ESF) had been approved, which meant SEK 125 million to the competence development programs (the budget item costs for personnel could only comprise of costs for internal and external teachers, not the salaries of employees who were to participate). Despite this, the management felt that further cost-cutting measures had to be taken in order to continue with the competence development and education programmes. New negotiations were thus initiated on a new collective agreement on a four-day workweek at 90 percent of original wages during the spring of 2010.

Even then, Scania's local negotiations were intertwined with negotiations on the industry level regarding a new agreement seeking to deal with the economic downturn. The employers' associations, with representatives from Scania at the forefront, were aiming for a new crisis agreement, while the unions were sceptical and said no. The employers were met with the same kind of reactions from the unions as when the previous four-day workweek agreement was introduced. For example, the unions were critical of the proposal as a 10 percent wage reduction was judged to be too hard on some members and there was still the risk of receiving smaller unemployment and illness benefits as well as the risk of being given notice despite a new agreement being in place. Even this time, unions were also worried that this type of crisis agreements would become the introduction to cyclically adjusted wages. The employers gave in, and agreements seeking to deal with the economic downturn would be in accordance with the existing collective agreement and settled on the local level. 
As a result, the local parties in Scania reached an agreement in the beginning of December 2009, which was to be valid from 1 January through 30 June 2010. The agreement was partially different from the company's crisis agreement. The most noticeable difference was that employees were now to work four days for a five-dayweek wage (i.e. without wage reductions). ${ }^{6}$ In other respects, the agreement was certain not to lead to reduced benefits from the social insurance or unemployment benefit fund. In addition, the company undertook not giving notice of dismissals owing to shortage of labour during the agreement period. The trade unions and the employees had to make certain concessions as well: The reduction in working hours, according to another agreement, which was not scheduled for 2010, was fixed for Fridays during the first quarter of the year. The employees also had to accept certain curtailments in the bonus system, which was based on quality and the amount of hours it took to build the trucks. The bonus for 2009 was entirely withdrawn, whereas the guaranteed amount of SEK 5,000 was removed for 2010 (the ceiling for the bonus was SEK 22,000). In addition, they had to accept a delay in the payment of their vacation supplement for 2010, which was postponed until March 2011. However, the union representatives on the national level as well as on the company level found the agreement satisfactory. For instance, a local blue-collar union representative argued that they "didn't lose so much" and that the agreement "was received much, much, much better" by the members.

\section{Termination of competence development and education}

In the spring of 2010 the market outlook for truck manufacturers improved. Production grew, and less time was available for competence development and education. Scania applied to the Swedish ESF Council for at sharply reduced budget. Only 54 million of the 125 million SEK would be spent. The application was approved, and for their part, the plant management teams in Södertälje, Oskarshamn and Luleå reduced their competence development and education programmes. For example, management in

6 However, not all employees were to work a four-day week during the entire period of the agreement. All employees were to work a four-day week during the first quarter, whereas personnel whose work depended on production volumes were to follow that schedule during both the first and the second quarters. 
Oskarshamn prematurely terminated some of the initiated competence development and educational programmes. Competence development programmes called "Education by the Week" and "Bonus Education", which were largely directed at Scania's production system, had been planned from January through June, although they were discontinued in March. Education programmes, such as full-time educational programs-which concentrated on secondary school level mathematics, Swedish and English as well as technology, Lean production, robotics, team development and leadership-were pursued up to the vacation period in July. ${ }^{7}$ Also, plant management and the trade unions agreed upon resuming the five-day workweek earlier than previously arranged. This was put into effect in May, whereas the original agreement extended until the end of June. Recruitment of new personnel began at approximately the same time. According to interviews with union representatives and management staff in Oskarshamn, all individuals who had previously been engaged on a temporary basis were asked whether they were interested in re-employment. This was done in accordance with the agreement on the right to be re-employed within 18 months. Of 98 previous employees in this category in Oskarshamn, 38 accepted the offer. Those who did not accept stated that they now had other employment or had begun studies. In addition, 97 individuals from the regular labour market were employed (on a temporary basis).

\section{Conclusions}

The economic downturn that broke out in autumn 2008 triggered Swedish employers' associations and blue-collar unions as well as white-collar unions in the industry to open up for local crisis agreements, which was a breakthrough for the employers. The unions had thus far rejected employers' suggestions to implement a variant of the German socalled opening clauses in the industry-level agreements, which allow companies both to conclude local agreements to deviate from agreed working time standards and to reduce

7 For the company as a whole and according to its own calculations, 70 percent of the time devoted to competence development and education had been concentrated to Scania's production system. Five percent had focused on production engineering and approximately 25 percent on the core subjects, mathematics, Swedish and English. 
wages in extraordinary times (Mandl and Schulze-Marmeling, 2010). However, the recession meant that the trade unions-IF Metall, in particular-were under heavy pressure: the downturn was exceptionally severe, and the employers were prepared to undertake dismissals. According to Kjellberg (2011), around 25 percent of IF Metall's members were expected to become unemployed during the year 2009; the ceiling of unemployment benefits was quite low (80 percent of SEK 18,700); many unemployed IF Metall members would receive benefits making up just 50-60 percent of their previous wage; there was no governmental financial support for training or severance pay in order to avoid or limit layoffs; costs for closing down were low compared to other countries; and there was a fear that transnational companies would phase out units in Sweden.

The unions' reaction was to collaborate with the employers to develop a system for handling downturns in the future. In cooperation, they investigated the short-time working systems in other European countries (Gruvornas Arbetsgivareförbund et al., 2011). The most interesting system seemed to be the German one. This systemgenerally regulated by law and under the responsibility of the federal governmentmeans, in brief, that employers are allowed to reduce the number of hours worked in times of temporary economic difficulties, that the time off is publicly financed with a sum which corresponds to the unemployment insurance, and that the state offers support for education and training (during the recession the government broadened this support) (Mandl and Schulze-Marmeling, 2010). In addition, the German system of short-time working is based on central and local agreements between employers, unions and works councils. Against this background, the labour market parties and the Swedish government discussed the possibility of implementing a solution that could match the German system. The unions and the employers became disappointed. In general, the government was positive to implementing a short-time working system; however, based on its study "State support for short-time work" (Finansdepartementet, 2012), the government did not support the employers and trade unions' wish to include competence development and education in its support. The government was of the opinion that it was the employers' responsibility that their employees had relevant 
competence and education for performing the job in an efficient manner-even during economic downturns. The talks between the labour market parties and the government are ongoing, and, for the moment, it is difficult to know what the result will be.

However, taking the unions and the employers' interest for training and education into account, Scania's way of handling the recession was the most advanced compared to other Swedish companies. In Scania, for instance, the crisis agreement on fewer working hours and lower wages included a deal not to give notice to anyone during the period of the agreement, and it was carried out in conjunction with comprehensive training and education programs. In other companies, the crisis agreements did not include a deal not to give notice to employees (many companies did give notice to employees) and were mostly not carried out in conjunction with education and skills development.

\section{Acknowledgements}

I would like to thank the two anonymous reviewers and the editor of Economic \& Industrial Democracy for their constructive feedback, enabling me to further develop and refine the article. Many thanks also to Anders Kjellberg at Lund University and Per Sederblad, Sandra Jönsson and Tobias Schölin at Malmö University for valuable comments on early drafts of the article.

\section{Funding}

The research project on which this article is based is sponsored by Vinnova, Sweden's Innovation Agency.

\section{References}

Abrahamsson L and Johansson J (2008) Framtidsfabriken. Rapport 2 Kunskapsöversikt. Det goda arbetet - igår, idag och imorgon. Luleå: Luleå tekniska universitet.

Ahlstrand R (2010) "Social responsibility in connection with business closures: A study of the closedown of Ericsson Telecom facilities in Norrköping and Linköping" in Economic and Industrial Democracy. 31 (4): 537-555. 
Ahlstrand R (2006) Strategier $i$ tiden. En studie av telekomföretaget Ericssons nedläggningar $i$ Norrköping och Linköping. Halmstad: Forskning i Halmstad nr 11, Högskolan i Halmstad. ISSN 1400-5409.

Ahlstrand R \& Sederblad P (2012) Teams, continuous improvement, the unions and conditional trust in the company Scania, Paper to the 16th International Workshop on Team working, Norwegian University of Science and Technology, Trondheim, Norway, September 6-7, 2012.

Anjou A (2008) Scanias framgång - betydelsen av strategisk kongruens och integrerad styrning. Linköping: Linköpings universitet-

Berggren C (1992) Lean Production - the End of the History? Stockholm: KTH. Institutionen för arbetsvetenskap.

Berggren C, Björkman T and Hollander E (1991) Är dom oslagbara? Reserapport från transplants, de nya japanägda bilfabrikerna i Nordamerika. Stockholm: KTH, Institutionen för arbetsvetenskap.

Bergström O and Diedrich A (2008) The Swedish model of restructuring. In Gazier B and Bruggeman F (eds) Restructuring Work and Employment in Europe. Managing Change in an Era of Globalisation Cheltenham: Edward Elgar Publishing Limited, pp. 141-167.

Bergström O, Håkansson K, Isidorsson T and Walter L (2007) Den nya arbetsmarknaden Bemanningsbranschens etablering $i$ Sverige. Lund: Academia Adacta.

Björkman, T (1991) "Lean production på svenska. Vad främjar respektive hindrar spridning av mager produktion i Sverige?" in Efter Taylor, Stockholm: Produktivitetsdelegationens och Arbetslivsfondens debattbok, pp. 107-128.

Brulin G, Ellström P-E and Svensson L (2012) Partssamverkan för effektiva produktionssystem och tillväxt. In Magnusson, L and Ottosson J (eds) Den hållbara svenska modellen - innovationskraft, förnyelse och effektivitet. Stockholm: SNS Förlag, 69-89.

Brulin, G \& Nilsson, T (1995) Läran om arbetets ekonomi. Om arbete och produktivitet $i$ modern produktion. Stockholm: Rabén Prisma.

Brulin G and Nilsson T (1991) "From Societal to Managerial Corporatism: New Forms of Work Organization as a Transformation Vehicle" in Economic and Industrial Democracy, Vol. 12, 327346.

Bäckström H (2006) "Arbetsmarknadsintermediärer - omställningar och institutionella förändringar på arbetsmarknaden" in Ekstedt E and Sundin E (eds) Den nya arbetsdelningen - arbets- och näringslivets organisatoriska omvandling i tid, rum och tal, Arbetsliv i omvandling 2006:11.

Edling C and Sandberg Å (1993) "Är Taylor död och pyramiderna rivna? Nya former för företagsledning och arbetsorganisation" in le Grand C, Ryszard, S \& Tåhlin, M (eds) Sveriges arbetsplatser. Organisation, personalutveckling, styrning. Stockholm: SNS Förlag.

Edström A and Sabel O (2005) Omstrukturering, omställning och kompetensväxling. GRI-rapport 2005:2 Göteborg: Handelshögskolan Göteborgs universitet.

Elvander N (2002) "The New Swedish Regime for Collective Bargaining and Conflict Resolution: A Comparative Perspective" in European Journal of Industrial Relations 8: 197-216.

Fagerström J (2004) Fallstudie på Scania CV AB. Stockholm: Kungl. Ingenjörsvetenskapsakademien (IVA).

Finansdepartementet (2012) Statligt stöd vid korttidsarbete, Stockholm: Finansdepartementet

Freyssinet J and Seifert H (2001) Negotiating collective agreements on employment and competitiveness. European Foundation for the Improvement of Living and Working Conditions, Luxembourg: Office for Official Publications of the European Communities.

Fucini J J and Fucini S (1990) Working for the Japanese. Inside Mazda's American Auto Plant. New York: Free Press.

Fukuyama F (1995) Trust: The Social Virtues and the Creation of Prosperity. London: Hamish Hamilton.

Garrahan P and Stewart P (1992) The Nissan Enigma. Flexibility at work in a local economy. London: Mansell.

Garaudel P, Noël F and Schmidt G (2008) "Overcoming the risks of restructuring through the integrative bargaining process: Two case studies in a French context" in Human Relations Vol 61(9): 12931331. 
Gruvornas Arbetsgivareförbund, IF Metall, Industri- och KemiGruppen, Stål och Metall, Arbetsgivareförbundet, Sveriges Ingenjörer, SVEMEK, Teknikarbetsgivarna och Unionen (2011) Korttidsarbete. Systemen i viktiga konkurrentländer. Stockholm: Gruvornas Arbetsgivareförbund, IF Metall, Industri- och KemiGruppen, Stål och Metall, Arbetsgivareförbundet, Sveriges Ingenjörer, SVEMEK, Teknikarbetsgivarna och Unionen.

Ilsöe A (2012) "The Flip Side of Organized Decentralization: Company-Level Bargaining in Denmark" in British Journal of Industrial Relations 50:4 pp. 760-781.

Jürgens U, Malsch T and Dohse K (1993) Breaking from Taylorism. Changing forms of work in the automobile industry. Cambridge: Cambridge University Press.

Kenney M and Florida R (1993) Beyond Mass Production. The Japanese System and its Transfer to the U.S. Oxford: Oxford University Press.

Kjellberg A (2011) "Trade Unions and Collective Agreements in a Changing World" in Thörnquist A and Engstrand $\AA \mathrm{K}$ (eds) Precarious Employment in Perspective. Old and New Challenges to Working Conditions in Sweden, Brussels: P.I.E Peter Lang, pp. 47-100.

Kjellberg A (2009) "The Swedish Model of Industrial Relations. Self-Regulation and Combined Centralisation-Decentralisation" in Phelan C (ed.) Trade Unionism since 1945. Towards a Global History, Oxford, Peter Lang, 2009, pp. 155-197.

Kjellberg A (1992). "Sweden: Can the Model Survive?" in Ferner A \& Hyman R (eds) Industrial Relations in the New Europe. Oxford: Basil Blackwell.

Kochan T (1992) "Walton and McKersie's Behavioral Theory of Labor Negotiations: An Industrial Relations Perspective” in Journal of Organizational Behavior, Vol. 13, No. 3, pp. 289-295.

Lundh C (2010) Spelets regler. Institutioner och lönebildning på den svenska arbetsmarknaden 18502010. Stockholm: SNS Förlag.

Mandl I and Schulze-Marmeling S (2010) Germany: Short-time working Allowance. Dublin, European Foundation for the Improvement of Living and Working Conditions (Eurofound).

Marginson P (2010) "New forms of co-operation, new forms of conflict" in Socio-Economic Review, 8 (2): $360-364$.

Metall (1985) Det goda arbetet. Stockholm: Metall.

Metall (1992a) Metalls bilgrupp: Japanska produktionskoncept i Nord Amerika. En rapport från en rundresa 18 januari - 1 februari 1992. Stockholm: Metall.

Metall (1992b) Metalls bilgrupp: Japanska produktionskoncept i Nord Amerika. En rapport från en rundresa 18 januari - 1 februari 1992. Bilaga. Stockholm: Metall.

Metall (1992c) "Mager produktion. Kan du jobba som en japan?" in Metallarbetaren Extra nr 47, 1-16.

Metall (1993) Amerikansk bilindustri och amerikanska bilarbetarförbundet. En rapport från verkstadklubbens studieresa i USA 1993. Stockholm: Metall.

Musial K (1999) "Institutionalisation of Scandinavian consensual democracy" in Folia Scandinavica Posnaniensia Vol 5, 59-73.

Nilsson T (1999) "The Future Role of the Swedish Unions Increased Local Cooperation for Production Development" in Economic and Industrial Democracy 20:461-482.

Parker M and Slaughter (1988) Shoosing Sides. Unions and the 'Team Concept'. Boston: South End Press.

Rehn G and Viklund B (1990) "Changes in the Swedish Model” in Baglioni G and Crouch C (eds) European Industrial Relations. The Challenge of flexibility. London: SAGE.

Reich R B (1994) Arbetsmarknad inför 2000-talet. Stockholm: SNS Förlag.

Rifkin J (1995) The End of Work. The Decline of the Global Labor Force and the Dawn of the PostMarket Era. New York: Tarcher/Putnam.

Ryan GW and Bernard HR (2003) Techniques to Identify Themes. Field Methods 15(1) pp. 85-109.

Scania (2008) Annual report. Scania: Södertälje.

Scania Inside Oskarshamn (2009) Hur har Scania bemött finanskrisen?, 4 Februari.

Sederblad P (2013) "Scanias produktionssystem - en framträdande modell i Sverige" in Sederblad P (ed) Lean i arbetslivet. Stockholm: Liber. 
SIF (1992a) Resurssnål bilindustri. Så påverkas tjänstemannaarbetet. Stockholm: SIF.

SIF (1992b) Produktionsnära tjänstemän. Företag och arbete i omvandling. Stockholm: SIF.

Sisson K (2001) "Pacts for employment and competitiveness - an opportunity to reflect on the role and practice of collective bargaining" in Transfer: European Review of Labour and Research, 7: 600615.

Sisson K and Artiles A M (2000) Handling Restructuring: Collective Agreements on Employment and Competitiveness. Luxembourg, Office for Official Publications of the European Communities.

SOU (1991:82). Drivkrafter för produktivitet välstånd. Stockholm: Produktivitetsdelegationen/Allmänna förlaget.

Thörnqvist C (1999) “The Decentralization of Industrial Relations: The Swedish Case in Comparative Perspective" in European Journal of Industrial Relations, Vol. 5, pp. 71-87.

Thörnquist A and Engstrand A K (2011) "Precarious Employment in Perspective" in Thörnquist A and Engstrand A K (eds) Precarious Employment in Perspective. Old and New Challenges to Working Conditions in Sweden, Brussels: P.I.E Peter Lang, pp. 11-22.

Teknikföretagen (2011) Industriavtalet. http://www.teknikforetagen.se/Documents/Arbetsratt/Industriavtalet.pdf?epslanguage=sv (2012-0315)

Teknikföretagen (2009) Lokala krisöverenskommelser i teknikföretag. Ekonomisk analys. http://www.teknikforetagen.se/hem/publicerat/nyheter/manga-teknikforetag-tecknar-krisavtal/ (2013-03-11).

Walton R E and McKersie R B (1991) [1965] A Behavioral Theory of Labor Negotiations: An Analysis of a Social Interaction System, 2. ed. Ithaca, N.Y.: ILR Press.

Womack JP Daniel TJ and Roos D (1990) The Machine that Changed the World. New York: Rawson Associates and Macmillan.

Roland Ahlstrand is senior lecturer in sociology and working life science at the Faculty of Education and Society, Malmö University, Sweden. His current research interests focus on corporate restructuring, industrial relations and work organisations. 